\title{
The Reflection of Anthropocentrism in the Current Context and the Ecological Design Strategy of Indoor Environment*
}

\author{
Zhao Xu \\ School of Design \\ Southwest Forestry University \\ Kunming, China 650224
}

\author{
Jing Guo** \\ School of Design \\ Southwest Forestry University \\ Kunming, China 650224 \\ **Corresponding Author
}

\author{
Yeqing Han \\ School of Design \\ Southwest Forestry University \\ Kunming, China 650224
}

\begin{abstract}
The purpose of this paper is to provide diversified theoretical support for the scientific development of human settlements design, explore the development direction of ecological design in indoor environment, hoping to provide reference for the design and research of human settlements environment. In the current context, the author elaborates on the reflection of anthropocentrism from the perspectives of ecological civilization, environmental protection, green development and human health, analyzes the concepts, principles, and methods of ecological design in indoor environments, and proposes the realization paths and technical measures of ecological interior design. The results show that the reflection on anthropocentrism and the study of the ecological design of the indoor environment, as well as the promotion of the development of ecological integration technologies, will provide a set of implementable technical routes for the construction of ecological buildings and indoor environments, which will offer pretty high theoretical and practical values for solving the environment and health problems caused by the decoration issues that is ubiquitous in current days.
\end{abstract}

Keywords-ecological civilization; indoor environment; ecological design; interior design; ecological interior design; anthropocentrism

\section{INTRODUCTION}

Human beings live in the world designed by nature and human beings themselves. In the global context, various ideas and awareness have had a tremendous impact on interior design and have influenced the development of modern interior design, such as ecology and environmental protection, resources and energy crisis, global integration and local

*Fund Project: This paper is a phased achievement of the 2017 Planning Project of Philosophy, Social Science and Art Science of Yunnan Province "Research on the dwellings Protection and Recycling Design of Traditional Villages in the Southwest of Yunnan Province in the Process of Urbanization" (Project Number: A2017YS15). protection. Since entering the 21 st century, along with the emergence of ecological and environmental problems, the western developed countries have proposed a new concept that rebuilds the natural outlook and values of "man is an integral part of nature". The ecological interior design is a very meaningful study. It is a kind of activity to create and improve the quality of human being's living environment. In the field of modern interior design, the concept of ecological design is becoming a dominant force. Ecological interior design respects nature and can fully reflect the scientific outlook on nature, values, and ethics. Although it is still a new topic under exploration in China and it is neither mature nor perfect, but in a certain sense, introducing interior design and expanding the connotation of interior design can push interior design to a higher level and realm.

\section{REFLECTION ON ANTHROPOCENTRISM IN CURRENT CONTEXT}

The anthropocentrism produced in modern society marks the great achievements in human epistemology and fully demonstrates people's conscious awareness of their own interests. It is known from the values theory that the great human practice has created the entire industrial civilization, but this civilization is just one-sided and temporary. It is worth pointing out that this concept of violating natural behaviors provides a stubborn theoretical basis for mankind's endless transformation of nature and destruction of the environment, ultimately leading to global environmental pollution problems. Therefore, when mankind constructs a post-industrial civilized society and begins to enter an ecologically-civilized society, it must profoundly reflect on this traditional anthropocentrism."Non-anthropocentrism" came into being in the social context of post-modernism. Its main point of view is that human interests are only part of the larger biosphere's interests. Mankind is only a member of the "biological 
community," and it is a "biological citizen" rather than a "natural ruler." Other natural objects outside of mankind also have its own intrinsic value, but not just an effective tool for satisfying human interests and needs. Human beings cannot start from their own small biosphere. Only when human beings proceed from the larger biosphere as a whole, human beings will have greater tolerance and security to the environment, so that the integrity and stability of the entire ecosystem can be truly protected. It can be seen that this concept has promoted the awakening of human ecological consciousness and has shifted the focus of traditional moral considerations from individualism to the overall system. This system fully demonstrates the coexistence and harmony of humans and the environment, and promotes the balance and development at a higher level between new environment and humans.

The beauty of design lies in its complexity, which often involves all aspects of life, including physiology, psychology, sociology, economics, ecology, and other factors. As the design concept is constantly updated, people's lives become rich and colorful. However, in the face of the crisis growth in today's society and the intensified human plundering of natural resources, the high consumption of resources and energy brought by modern interior design, and the ecological problems caused by serious damage to the environment are no longer a simple technical problem, which fully reflects that the ecological interior design of sustainable development has been put on the agenda, and will gradually develop into the mainstream of modern interior design.

Designers carry out indoor space arrangements and ideas from the people-centered principle, such as the use of expensive and rare decorative materials at all costs, but ignoring the environmental pollution caused by materials in the process of processing and transportation, the blind pursuit of luxury complex interior design style and the use of nondegradable non-green decorative materials. These acts seriously threaten people's living environment, affect people's quality of life, and bring great harm to people's physical and mental health. In addition, the visual pollution caused by inappropriate lighting configuration and unreasonable color planning of designers in interior design, and noise pollution generated during the use of indoor physical environment are all specific to anthropocentrism in the indoor environment. Only by paying attention to these issues, following the principle of ecology, and using resources effectively and rationally, can we reduce damage to nature and avoid serious harm to people's health.

\section{ANALYSIS OF ECOLOGICAL DESIGN STRATEGIES IN INDOOR ENVIRONMENT}

The term "ecology" originates from ancient Greece, meaning the home or the natural environment, or the survival and developing state of creatures in a certain natural environment. In today's society, ecology has penetrated into all fields, and the term "ecology" has become more and more extensive. People often use "ecology" to define many good things, such as the things that are healthy, safe, harmless, and beautiful and harmonious can be modified with the word "ecological."According to the UN report, by the year 2050, the growth of the earth's population and the development of urbanization are expected to increase by 2.5 billion people. The resources needed to adapt to this development will be too large to bear. Therefore, the protection of the ecological environment and sustainable development are the most pressing issues facing the world in the 21 st century. It can be seen that ecological architecture has become a hot issue in current architecture research. The so-called ecological architecture refers to the theory and method of architectural planning based on ecological thinking. In general, it means that uses the principle of ecology to regard architecture and indoor environment as overall system, which is organic, structured and functional. It aims at the coordinated development of people, architecture, nature and society, and uses and reforms natural resources sparingly to seek the architectural and indoor environment that is most suitable for human survival and development and in line with the concept of ecological civilization.

Ecological design in the indoor environment (i.e., ecological interior design) is an extremely important content in the study of ecological architecture. In fact, the environmental problems and social problems caused by interior design, if not resolved in time, are likely to develop into a "disease" that destroys the ecological environment, thereby increasing the difficulty of environmental governance. Ecological interior design is a sustainable design. The basic idea is to incorporate environmental influence factors and pollution prevention measures into the design process at the design stage. Environmental performance will be taken as the design goal and starting point to minimize the impact of the design results on the environment. In addition, from the perspective of comprehensive governance, the concept of eco-environmental protection and energy conservation should be incorporated into the design as much as possible. In accordance with the principle of coordinated symbiosis, the recycling, sustainable self-production, the energy utilization optimization, and the principle of minimization of waste production, the design plan shall be revised and improved comprehensively and strive to achieve the best design results. Among them, ecological interior design is an important part of ecological architecture. Environmental factors have become the core issue of ecological interior design. The technological content of ecological interior design focuses on energy conservation and harmlessness as well as the space use of the environment and energy development.

\section{A. Ecological Beauty}

Ecological beauty is a new development of aesthetics. It adds ecological factors into the traditional aesthetic content, emphasizes the "natural ethics view", to realize the harmonious relationship between the human residence environment and natural ecology, take effort to maintain the ecological balance, and pursue the perfection combination of natural beauty and artificial beauty. Ecological beauty is harmonious and organic, natural, plain and concise, without deliberate decoration. Ecological beauty is also of high level, it emphasizes on the reconstruction of nature fully by scientific and technological means under the premise of following the laws of ecology and beauty, the creation of artificial ecological beauty, and the appreciation of integration of indoor landscape 
and outdoor nature by artificial creation, which brings a lasting spiritual pleasure, rather than temporary visual experience.

\section{B. Localization}

The relationship between human and nature is symbiotic and cooperative, and the cooperation in accordance with the process and pattern of life can significantly reduce the impact of artificial design on the ecological environment. McHarg believes that the design method is to "take the least effort to adapt to nature" instead of contention. The ecological view of natural integration is a method and strategy of designers to implement ecological interior design. From the viewpoint of environmental protection and energy conservation, localization not only is of external form, but also used in all aspects of design work from content, such as the localization of decorative materials, the localization of spatial processing, and the localization of indoor environment. Therefore, the localization design highlights the honest and strong regional beauty, for which we should follow the principle of local materials and local conditions to fully find the aesthetic elements of traditional culture and regional culture that are beneficial to the environment, and maximize the utilization of original features of local resources, to create an indoor environment suitable for living of human.

\section{Energy Saving}

Energy-saving is to improve the utilization efficiency of energy, not only to reduce material waste and energy consumption, but also to emphasize the full and reasonable application of natural resources such as sunlight, air, and water into indoor environments by modern science and technology in the creation, use and renewal of indoor environment, further to maximally meet people's physical and psychological demand. For example, the combination of configuration of the finished assembly product of new materials such as heat-absorbing glass, heat-reflecting glass, light-adjusting glass, and heatinsulating wall with the interior design, can achieve the dual effects of heat preservation and lighting and greatly save energy. At the same time, the full use of energy-saving lamps and water-saving components in interior design can also achieve the effect of energy saving. It can be seen that saving and recycling of non-renewable resources and conventional energy in the ecological interior design, and the lowconsumption use and recycling of renewable resources are the basic means for the development of ecological buildings and indoor environment, and also the basic features of ecological interior design. In addition, designers should try to choose the furniture made of renewable or recycling materials, to use new green energy-saving electrical products, especially to pay attention to the lighting, ventilation, deodorization, grease proofing, etc.

\section{Harmlessness}

Harmlessness is required for the indoor environment and decorations. It requires the reduction of emission of harmful substances, so the pollution-free recyclable decorative materials are often used. Because a large area of decorative materials can create a luxurious and grand style, but the longterm contact of human with the decorative interface or the use of harmful substances in the exposed areas, will easily cause harm to people's health, especially the use of artificial board with excessive emission of formaldehyde and the granites with excessive radioactive elements. Therefore, designers must establish environmental protection awareness for their creative methods and attach importance to environmental protection requirements. They must consider whether decorative materials will have an impact on people's health and cause a pollution of people' living environment, and actively use some non-toxic and harmless green decorative materials to ensure that the design program is green and healthy. In addition, the government should increase penalties for the enterprises of harmful decorative materials, and whether the air quality is qualified after decoration or not, should be tested and controlled by a professional indoor environment testing agency.

\section{E. Moderate Consumption}

People is requiring a higher and higher material standards of living, and they have a increasing demand for improvement of their residential living environment, so they are willing to spend more money to improve their living environment; while the indoor environment created by designers is not only a kind of consumption, but also an important part of human consumption. The interior design is purposed to create a comfortable and beautiful living environment, and the ecological interior design emphasizes a moderate consumption, advocates a low-carbon and saving lifestyle, against extravagance and waste in interior design. The excessive decoration inevitably consumes more decorative materials and causes more environmental pollution, so the production and consumption within the scope of endurance of resources and environment will ensure the sustainable development of ecological environment, and it fully embodies a new ecological concept and values.

\section{THE WAY TO ACHIEVE THE ECOLOGICAL INTERIOR DESIGN AND ITS TECHNICAL MEASURES}

\section{A. The Way to Achieve the Ecological Interior Design}

People have different attitudes in their pursuit of material life, which will brings about the sacrifice of limited environmental resources of human beings, so ecological interior design requires the guiding role of national policies and laws and regulations. Today, China greatly advocates a resource-saving and environment-friendly society, which is conducive to the formulation of relevant laws and regulations by the government departments as soon as possible. Only when laws and regulations are used to restrict people's behavior and restrict the irregular decoration market, can people have further environmental awareness, and the ecological interior design be implemented, promoted and realized. At the same time, in ecological interior design, designers must strictly abide by relevant laws and regulations and carefully consider the environmental protection of decorative materials, the rationality of spatial functions, the conservation and sustainable development of material resources. Besides, the decoration market concerns the vital interests of people, so the establishment and improvement of market management mechanism is the key to the development 
of ecological interior design. To implement the ecological design of the indoor environment, government departments must establish a strict qualification standard for decoration companies, carry out qualification check for all companies enter the market, set up and improve the project supervision systems, strengthen the education of environmental protection, develop environmental protection activities, and encourage technological innovation.

\section{B. Technical Measures for Ecological Interior Design}

In China, there is not a comprehensive standards for energy saving, water saving, land saving, material saving, and environmental protection, and lagging laws and regulations is to be improved, so we should fully consider China's national conditions and the characteristics, such as lack of resources, and large population, to encourage enterprises and individuals to make a active investment in ecological projects. The developed countries have relatively mature eco-architectural design and indoor ecological design, so domestic designers should actively study their technical measures of indoor ecological design, to promote the coordinative development of ecology and economy, and establish a strict eco-architecture evaluation system standard to prevent arbitrary abusement of the concept of eco-architecture and indoor environment, providing a set of implementable technical routes for the construction of ecological buildings and indoor environments. For example, Germany has the leading ecological architecture in the world, and its advanced eco-technological measures benefit from the positive attitude of the federal government towards environmental protection. The German government has vigorously developed clean energy such as water, geothermal, wind energy, solar energy, bioenergy, etc., and it promoted the advanced energy conservation technology to fully improve the utilization efficiency of energy; besides, for a large number of old buildings that do not adopt new insulation technology measures, the German government carried out new regulations to encourage enterprises and individuals to make a energy-saving renovation of old buildings, and it implemented mandatory scrapping measures. All these have a high reference for research on ecological interior design.

\section{CONCLUSION}

The ecological environment in China has a big gap from that in the developed countries, including the natural environment, the cultural environment and the social environment, so we must first practically introduce the concepts and ideas and consider the current situation in China, to wisely solve the problems of ecological environment, leading to a comprehensive and sound development of ecological interior design. It has been demonstrated by a large number of examples, ecological buildings and indoor environments have wide unknowns, ecological interior design has its enormous potential of development, and in the era of knowledge-based economy, the development of high eco-tech industries is a right choice for benefiting a nation and people.

It is inevitable to return to nature and make ecological design for social development. As an effective and important way to solve current environmental pollution, we must get rid of the anthropocentrism and advocate ecological interior design. Today, the concept of ecological indoor design is becoming a dominant force, and as a new trend of indoor environment in the future, people will pay more attention to ecological environment and individualized performance, and fully present the design theme of health, environmental protection and sustainable development, further to give new vitality of human residence environment, for which designers should do a hard work.

\section{REFERENCES}

[1] Wu Liangyong. Scientific Introduction of Human Residence Environment [M]. Beijing: China Architecture \& Building Press, 2001. 吴良镛.人居环境科学导论 $[\mathrm{M}]$.北京:中国建筑工业出版社, 2001.

[2] Xia Yun, Xia Kui, Shi Yan. Ecological and Sustainable Architecture [M]. Beijing: China Architecture \& Building Press, 2001. 夏云,夏葵,施 燕.生态与可持续建筑[M]. 北京:中国建筑工业出版社, 2001.

[3] Liu Jiecheng. Research on the Interaction of Humanity, Intelligence and Ecologicalization in Indoor Space Design [D]. Master thesis of Wuhan University of Technology, 2003. 刘杰成.室内空间设计中人性化、智 能化、生态化的交互研究[D].武汉理工大学硕士学位论文, 2003.

[4] Ma Chundong. Ecological Design [M]. Beijing: Higher Education Press, 2007. 马春东.生态设计[M].北京:高等教育出版社, 2007.

[5] Zhu Kui. Research on the Architectural Design of Indoor MicroEnvironment of Green Ecological Residence [D]. Dissertation of Tianjin University, 2007. 朱奎.绿色生态住宅室内微环境建筑设计研 究[D].天津大学硕士学位论文, 2007.

[6] Liu Xianjue. Ecological Architecture [M]. Beijing: China Architecture \& Building Press, 2009. 刘先觉.生态建筑学 [M]. 北京:中国建筑工业 出版社, 2009 .

[7] Zhang Yina. Concept Awareness And Innovation of Interior Decoration Design[J]. Urban Construction Theory Research, 2012(7). 张奕娜.室内 装饰设计的观念意识与创新 [J].城市建设理论研究, 2012(7).

[8] Lu Yiran. A Brief Talk on the Consciousness of Ecological Balance in Interior Design[J]. Journal of North University of China (Social Sciences Edition), 2013(05). 卢祎然.略谈室内设计的生态平衡意识 $[\mathrm{J}]$ 中北大学学报(社会科学版), 2013(05).

[9] Han Yeqing, Xu Zhao. Research on Ecological Interior Design out of Anthropocentrism[J]. Art Science and Technology, 2013(11). 韩叶青, 徐到. 走出人类中心主义的生态室内设计研究 [J]. 艺术科技, 2013(11). 